\title{
RELATIONSHIPS BETWEEN SPORT, WORK AND LEISURE-TIME PHYSICAL ACTIVITY AMONG LITHUANIAN UNIVERSITY STUDENTS
}

\author{
Brigita Miežienė, Laimutis Šiupšinskas, Rasa Jankauskienė \\ Lithuanian Academy of Physical Education, Kaunas, Lithuania
}

\begin{abstract}
Research background and hypothesis. Other than sport physical activity which occurs in occupational, leisure and domestic sectors is often overlooked, meanwhile it also affects health. Previous research revealed that energy expenditure in occupational, domestic and leisure-time domains may influence energy expenditure in sports or exercising domain. University students are understudied population in this area. We expected that lower work and leisure-time activity among university students would be associated with their higher sports related activity.

Research aim was to examine relationships between sport, work and leisure-time activities in a sample of university students.

Research methods. The final sample consisted of 867 students from four Lithuanian universities, 195 (22.5\%) were males, their age ranged from 18 to 22 years. Baecke Questionnaire of Habitual Activity (Baecke et al., 1982) was used to assess work, leisure-time and sport physical activity.

Research results. Male students scored significantly higher than female in work and sport activity $(\mathrm{p}<0.0001)$, but not in leisure-time activity $(\mathrm{p}=0.61)$. Males and females who were more active in their occupational domain were also twice more active in sports-related activities $(\mathrm{OR}=2.22$ [95\% CI $1.25-3.93]$ and $\mathrm{OR}=2.14$ [95\% CI, $1.50-3.04]$ respectively). Females who were more active in leisure-time domain were almost twice more active in sports-related activities (OR $=1.65[95 \%$ CI 1.22-2.21]) as well.

Discussion and conclusions. Analysis of the relationships between sports, work and leisure-time physical activities did not confirm our expectation. The results of the current study revealed that lower physical activity in occupational or leisure-time domains did not determine higher sports related physical activity. Sports-related activity and physical activity in other domains can coexist together in the population of students and possibly depends on variables which influence them all. In further research, the broader set of variables influencing university students' habitual physical activity should be taken into account.
\end{abstract}

Keywords: habitual physical activity, physical activity domains, occupation of university students.

\section{INTRODUCTION}

$\mathrm{P}$ hysical activity is defined as any bodily movement produced by skeletal muscles that results in energy expenditure above the resting level (WHO, 2011). Regular physical activity is one of the most important factors in health promotion. It not only improves mood, but also is definitely beneficial to physical health
(WHO, 2011). Adequate physical activity reduces risk of cardiovascular disease, diabetes and even certain forms of cancer, helps control weight and improves mental health. Participation in physical activities helps to make friends and feel part of the community (Castillo, Garcia-Molina, 2009) as increased physical activity is associated with 
higher levels of social support and self-efficacy (Maglione, Hayman, 2009; Shuval et al., 2009). On the contrary, physical inactivity is associated with many chronic diseases and obesity (Baba et al., 2006) and is among the 10 leading causes of mortality and morbidity around the world (WHO, 2002).

Assuming that years while studying make a great impact on the young people consciousness, this is an opportune time point for implementation and fixing ideas about healthy lifestyle. Besides, students are supposed to be an educated part of the society and are expected in the future to spread ideas and be an example for certain groups in society. Data about students' physical activity is important in assessing their health status, predicting the changes and trends of public health development, planning health promotion and disease prevention strategies.

Up to now, many studies revealed that physical inactivity is a serious health problem among university students. A cross-sectional survey in 23 countries identified that the prevalence of inactivity in leisure time varied, averaging 23 percent in North-Western Europe and the United States, 30 percent in Central and Eastern Europe, 39 percent in Mediterranean countries, 42 percent in Pacific Asian countries, and 44 percent in developing countries (Haase et al., 2004). Moreover, another study reported that, for example, in Canada 65 percent of students were insufficiently physically active (Irwin, 2007).

Understanding of physical activity is sometimes associated with sport and exercising, but physical activity and exercising actually, reflect different things. Physical activity is a broader concept than physical exercise; it is a complex and multidimensional exposure variable and includes several domains - occupational, domestic and leisure (Ono et al., 2007; Jankauskiene, 2008).

An international study, which reviewed and analyzed the prevalence of university students' participation in physical activity at the level necessary to acquire health benefits, revealed that female students were less active than male students (Irwin, 2004). Results of some other cross-cultural studies are in accordance with the previous research (Seo et al., 2009).

According to K. R. Evenson and colleagues (2003), physical activity that occurs in the occupational and domestic sectors is often overlooked (Evenson et al., 2003). While it has an important effect on body weight (Monda et al., 2008), cardio-vascular dicease in later life (Wang et al., 2010) and self-rated health (Parkes, 2006). A large number of research examining physical activity has largely focused on sports and physical exercise rather than other sources of energy expenditure, such as occupational or work activity and leisure-time activity. Thus the actual data about habitual physical activity could be incomplete.

Results of some previous research about relationships of sports, work and other than sports leisure-time activities are contradicting. Research in the USA shows, that the level of work and leisure-time activity may negatively influence energy expenditure in sports and exercising domain (Evenson et al., 2003). On the contrary, the study in Australia revealed that white-collar employees were less likely to engage in sufficient physical activity and more likely in occupational sitting than blue-collar employees (Duncan et al., 2010). Meantime, a study in the USA with racial or ethnic minorities and study in Brazil showed that occupational and housework physical activity were not related to participation in physical exercise in leisure (Marquez et al., 2010; Rombaldi et al., 2010). So, the research of the relationship of various types of physical activity is still important. Particularly university students are understudied population in this area. While their prime occupation, i. e. studying, is supposed to be associated with sitting and this fact is not positively related to their health (Duncan et al., 2010). The aim of the study was to examine relationships between sport, work and leisure-time activities in a sample of university students. We hypothesize that lower work and leisure-time activity of university students would be associated with their higher sports-related activity.

\section{RESEARCH METHODS}

Participants. The initial sample of participants included 1036 of university students. 169 students failed to complete questionnaires correctly. The final sample consisted of 867 students from four Lithuanian universities, 195 (22.5\%) were males and $672(77.7 \%)$ females, who ranged in age from 18 to 22 years. Lithuanian University of Health Sciences (LUHS) was represented by 421 student, studying medicine, odontology, pharmacy and public health. There were 235 students from 
the Lithuanian Academy of Physical Education (LAPE), Faculties of Sports Biomedicine and Sports Education participated in this study, and 101 students were from the Lithuanian Music and Theatre Academy (LMTA). These students were studying music and music performancerelated sciences. Finally, 110 students were from Mykolas Romeris University (MRU), studying social sciences.

Instruments. Baecke Questionnaire of Habitual Activity (Baecke et al., 1982) proved to have high reliability and accurate assessment of heavy intensity activity as well as light intensity activities. Additionally it fits for both men and women (Richardson et al., 1995). It was proved by research that the Baecke Questionnaire of Habitual Activity can provide valid data about physical activity (Philippaerts et al., 1999). The questionnaire consisted of 16 items, classified into three scales: work, sports, and leisure-time activity, which measure self-assessed activity referring the past 12 months. The first scale, work activity, consists of eight questions reflecting the occupation-related physical activity. All occupations in this questionnaire are classified into three groups based on physical activity levels and each group assigned a corresponding score (1-st item). The 2-8 items assess individual workrelated physical activity. As the population in target was university students, work activity was considered as activity while studying. The second scale, sport activity, reflects the casual sportsrelated physical activity. Taking into account that different sports related to different amount of energy expenditure, two out of four items estimate that. The third scale, leisure-time activity, also consists of four items. Non sport-related activity, such as watching television, riding a bike, walking to and from work, which also utilized certain amount of energy, is included into leisure-time activity scale.

Demographic information included age and gender.

Statistical analysis. Students' sample was divided into two groups depending on the means of the sport, work as well as leisure-time activity indexes. More and less physically active groups were obtained. Binary logistic regression analysis was used to assess the relationship between sport, work as well as leisure-time activity and university variable. Students from LUHS were considered as a reference group. Gender as a control variable was included into the equation. Descriptive statistics was used to calculate means and standard deviations (SD).

Gender differences of habitual physical activity were determined by a Mann-Whitney test for nonparametric data. Percentage distribution of exercising, occupational sitting, sitting at a computer or watching TV were calculated using $\chi^{2}$ statistic.

Finally, binary logistic regression analysis was used to assess the relationships between sport, work and leisure-time physical activity. Predictive value of work and leisure-time activity variables for greater sport activity index were evaluated.

\section{RESEARCH RESULTS}

Differences of habitual physical activity between universities. First, prevalence of sport, work and leisure-time physical activity between universities was compared. Results of binary logistic regression analysis (Table 1), adjusted for gender, showed that students from LAPE and MRU were more likely to be classified as more physically active in sports $(\mathrm{OR}=3.52$

Table 1. Logistic regression models of habitual physical activity prevalence between universities showing adjustment for gender odds ratios (with $95 \%$ confidence intervals)

\begin{tabular}{|l|c|c|c|c|c|c|}
\hline \multirow{2}{*}{ University } & \multicolumn{2}{|c|}{ Sport activity } & \multicolumn{2}{c|}{ Work activity } & \multicolumn{2}{c|}{ Leisure-time activity } \\
\cline { 2 - 7 } & Mean SD & OR (CI 95\%) & Mean SD & OR (CI 95\%) & Mean SD & OR (CI 95\%) \\
\hline LUHS & $2.62 \pm 0.48$ & Ref. & $2.12 \pm 0.41$ & Ref. & $3.17 \pm 0.54$ & Ref. \\
\hline LAPE & $2.99 \pm 0.66$ & $3.52(2.49-4.98) * *$ & $2.34 \pm 0.54$ & $1.61(1.16-2.24) * *$ & $2.96 \pm 0.58$ & $0.60(0.43-0.84) *$ \\
\hline LMTA & $2.75 \pm 0.60$ & $1.54(0.96-2.44)$ & $2.51 \pm 0.52$ & $2.97(1.86-4.74) * *$ & $3.44 \pm 0.58$ & $2.13(1.33-3.39) *$ \\
\hline MRU & $2.95 \pm 0.44$ & $3.37(2.18-5.22) * *$ & $2.02 \pm 0.46$ & $1.32(0.86-2.01)$ & $3.07 \pm 0.47$ & $0.70(0.46-1.07)$ \\
\hline
\end{tabular}

Note. $*-p<0.05 ; * *-p<0.0001$. 


\begin{tabular}{|l|c|c|}
\hline \multicolumn{1}{|c|}{ Variable } & $\begin{array}{c}\text { Male } \\
\text { OR (CI 95\%) }\end{array}$ & $\begin{array}{c}\text { Female } \\
\text { OR (CI 95\%) }\end{array}$ \\
\hline Work activity & $2.22(1.25-3.93) * *$ & $2.14(1.50-3.04) * *$ \\
\hline Leisure-time activity & $0.96(0.58-1.59)$ & $1.65(1.22-2.21) * *$ \\
\hline
\end{tabular}

Table 2. Logistic regression models showing relationships of sport, work and leisuretime physical activity in male and female university students (odds ratios with $\mathbf{9 5 \%}$ confidence intervals)

Note. $* *-p<0.0001$

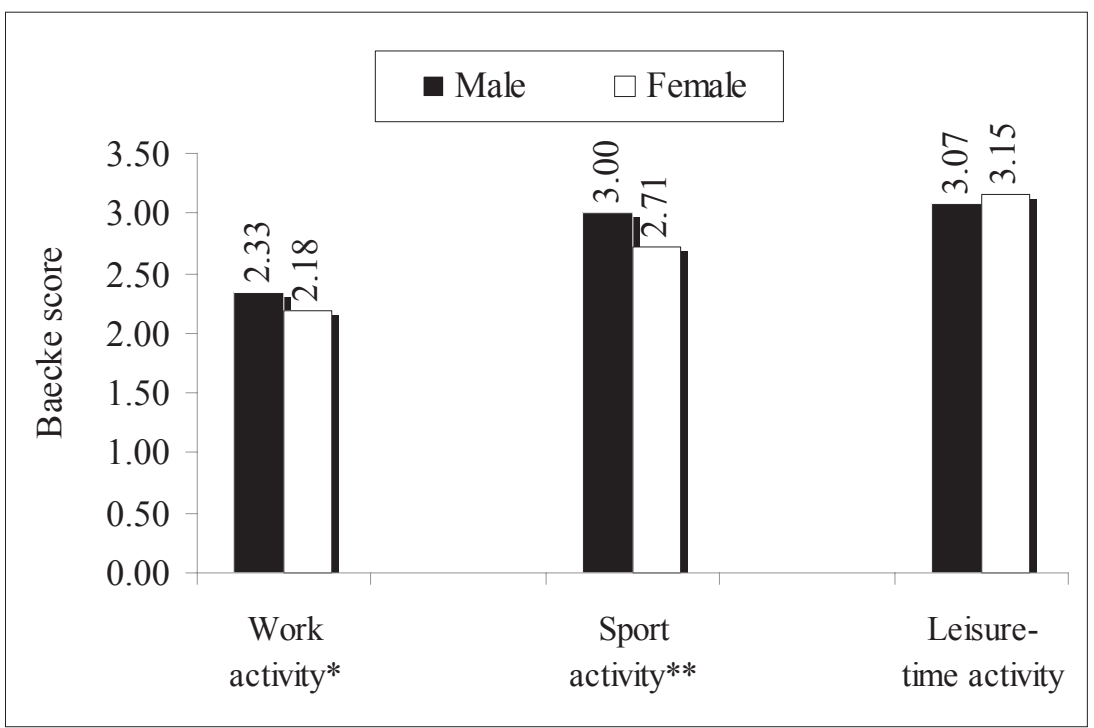

Figure. Habitual physical activity indexes in male and female students

[95\% CI 2.49-4.98] and 3.37 [95\% CI 2.18-5.22] respectively; $\left.\chi^{2}=103.21 ; \mathrm{df}=4 ; \mathrm{p}<0.001\right)$ as compared to LUHS students. Students from LAPE and LMTA were more active at work $(\mathrm{OR}=1.61$ [95\% CI 1.16-2.24]; and 2.97 [95\% CI 1.86-4.74] respectively; $\left.\chi^{2}=35.22 ; \mathrm{df}=4 ; \mathrm{p}<0.001\right)$; and also students from LMTA were more likely to be active in other than sports leisure-time activity $(\mathrm{OR}=2.13[95 \%$ CI 1.33-3.39]) as compared to LUHS students. But LAPE students had lower odds to be active in leisure than LUHS students $(\mathrm{OR}=$ 0.60 [95\% CI 0.43-0.84]); model's $\chi^{2}=31.62$; $\mathrm{df}=4 ; \mathrm{p}<0.001$.

Gender differences of habitual physical activity. Further, we evaluated and compared occupational sitting between genders. Results showed that 79.5 percent $(n=155)$ of male and 85.4 percent $(n=574)$ of female students agreed that their occupation was always or very often related with sitting. Only $8.2(\mathrm{n}=16)$ and 7.4 percent $(n=50)$ of male and female students reported that their sitting was not habitual or was just rarely related to their work. Reported occupational sitting between males and females did not differ $\left(\chi^{2}=6.53 ; \mathrm{df}=4 ; \mathrm{p}=0.16\right)$.

Only one $(0.5$ percent $)$ male student and 1 percent $(n=7)$ of female students reported that they sat at the computer or watched TV always, $20(n=39)$ and 23.1 percent $(n=155)$ respectively agreed that they did that often, 36.4 $(\mathrm{n}=71)$ and 36.5 percent $(\mathrm{n}=245)$ respectively sometimes, $38.5(\mathrm{n}=75)$ and $33.3(\mathrm{n}=224)$ respectively - rarely, and small percent -4.6 $(\mathrm{n}=9)$ and $6.1(\mathrm{n}=41)$ respectively declared that they never sat at computer or watched TV in leisure time. Results distributed in a similar way between male and female students $\left(\chi^{2}=2.82\right.$; $\mathrm{df}=4 ; \mathrm{p}=0.59$ ).

$\chi^{2}$ statistic revealed that 92.3 percent $(n=180)$ of male and 61.3 percent $(n=412)$ of female students reported that they exercised or played sports in leisure time. Obviously, more male than female students exercised $\left(\chi^{2}=67.06 ; \mathrm{df}=1\right.$; $\mathrm{p}<0.0001$ ).

The Mann-Whitney test was applied to assess the differences of work activity, sport activity and leisure-time activity indexes between male and female students. The test results revealed (Figure 1) that males scored significantly higher than female students on work and sport activity (Mann-Whitney $U=55376 ; p=0.001$ and MannWhitney $U=46402 ; p<0.0001$ respectively). Leisure-time activity index didn't differ between the groups (Mann-Whitney $\mathrm{U}=59811$; $\mathrm{p}=0.61)$.

Relationships between sport, work and leisure-time physical activity. Results of binary logistic regression analysis in the male group of students (Table 2) indicated that only work activity was associated with sport activity. The greater 
the work activity index, the higher the odds of being classified as more physically active in sports $\left(\mathrm{OR}=2.22\right.$ [95\% CI 1.25-3.93]; $\chi^{2}=8.11 ; \mathrm{df}=2$; $\mathrm{p}=0.02)$.

Logistic regression analysis in female group of students revealed (Table 2) that both greater work and leisure-time activity indexes were associated with greater sport activity $(\mathrm{OR}=2.14$ [95\% CI, 1.50-3.04] and 1.65 [95\% CI 1.22-2.21] respectively; $\chi^{2}=32.27 ; \mathrm{df}=2 ; \mathrm{p}<0.001$ ).

\section{DISCUSSION}

By the current research we tried to identify the impact of occupational and leisure-time activities for students' participating in sports activities. It was proposed that lower work and leisure-time activity of university students would be associated with their higher sports related activity. Analysis of the predicting factors of higher sports-related activity did not confirm our expectations. The results of the current study revealed that lower physical activity in occupational or leisuretime domains did not determine higher sports related physical activity. On the contrary, male and female students who were more active in their occupational area, were also twice more active in sports-related activities. Higher leisuretime activity was associated with higher sports related activity in females, but it was associated in males. P. C. Rouse and S. J. H. Biddle (2010) revealed in their research that leisure-time activities related to sedentary technology, which includes TV watching and computer gaming, was associated with higher physical activity in male, but not female students, but this relation was slight. So, the authors concluded that these slight relationships suggest that technological sedentary behaviours and physical activity do not compete significantly for time and can coexist as part of a student's lifestyle (Rouse, Biddle, 2010). But research in older population produces different results. Our results contradict to the results obtained in the USA and Brasil, where authors did not find any relationship between work and sports activities in working age adults (Marquez et al., 2010; Rombaldi et al., 2010). But K. R. Evenson and colleagues (2003) revealed that those middleaged adults with the highest occupational activity had lower participation in any sports than those with lower occupational activity across gender groups.
The results of the current study also provide important evidence that occupation of most students is predominantly related with sitting. Though, that is not surprising, because the main occupation of students is supposed to be studying, which is in turn associated with sitting. In the study in England, P. C. Rouse and S. J. H. Biddle (2010) also revealed that studying was the predominant sedentary activity among students followed by the sedentary technology (Rouse, Biddle, 2010). But in our study only one fifth of students, both males and females, sat at the computer or watched TV in their leisuretime. Furthermore, nine out of ten male students and more than a half of female students reported exercising or participating in sports regularly. Significantly more male than female students are physically active. The latter finding was expected and was already confirmed in Lithuania (Puišienè et al., 2008) as well as in many other countries (Irwin, 2004; Seo et al., 2009).

There is a lack of research about physical activity differences between universities in Lithuania. Our study add some evidence revealing that students form LAPE were more active at sports than other students who participated in this study. Also they were among the most active ones at work. The results obtained are not surprising because physical activity is an integrated part of studies at LAPE.

\section{CONCLUSIONS AND PERSPECTIVES}

So, on the basis of the current research we can conclude that students, especially females, if they were physically active, they were active in all domains of life, and vice versa. We suggest that sports-related activity and physical activity in other domains can coexist together in the population of students and possibly depend on variables which were not studied in this research and which influence all of them. In further research, the broader set of variables, possibly predicting university students' habitual physical activity, should be taken into account.

Acknowledgments. The authors would like to thank Assoc. Prof. E. Puišienè, Assoc. Prof. R. Baublienè and doctoral student J. Čepelionienè for their assistance in organizing the survey. 


\section{REFERENCES}

Baba, R., Iwao, N., Koketsu, M., Nagashima, M., Inasaka, H. (2006). Risk of obesity enhanced by poor physical activity in high school students. Pediatrics International, 48, 268-273.

Baecke, J., Burema, J., Frijters, J. (1982). A short questionnaire for the measurement of habitual physical activity in epidemiological studies. The American Journal of Clinical Nutrition, 36, 936-942.

Castillo, I., Molina-Garcia, J., Pablos, C. (2009). Determinants of Leisure-time Physical Activity and Future Intention to Practice in Spanish College Students. The Spanish Journal of Psychology, 12 (1), 128-137.

Duncan, M. J., Badland, H. M., Mummery, W. K. (2010). Physical activity levels by occupational category in non-metropolitan Australian adults. Journal Of Physical Activity \& Health, 7 (6), 718-723.

Evenson, K. R., Rosamond, W. D., Cai, J., Pereira, M. A., Ainsworth, B. E. (2003). Occupational physical activity in the atherosclerosis risk in communities study. Annals of Epidemiology, 13 (5), 351-357.

Haase, A., Steptoe, A., Sallis, J. F., Wardle, J. (2004). Leisure-time physical activity in university students from 23 countries: Associations with health beliefs, risk awareness, and national economic development. Preventive Medicine, 39 (1), 182-190.

Irwin, J. D. (2004). Prevalence of university students' sufficient physical activity: A systematic review. Perceptual and Motor Skills, 98 (3 Pt 1), 927-943.

Irwin, J. D. (2007). The prevalence of physical activity maintenance in a sample of university students: A longitudinal study. Journal of American College Health, 56 (1), 37-41.

Jankauskiene, R. (2008). Lietuvos gyventojų fizinio aktyvumo skatinimo strategija: kūno kultūra ar kūno kultas? Medicina, 44 (5), 346-355.

Maglione, J. L., Hayman, L. L. (2009). Correlates of physical activity in low income college students. Research in Nursing \& Health, 32 (6), 634-646.

Marquez, D. X., Neighbors, C. J., Bustamante, E. E. (2010). Leisure time and occupational physical activity among racial or ethnic minorities. Medicine and Science in Sports and Exercise, 42 (6), 1086-1093.

Monda, K. L., Adair, L. S., Zhai, F., Popkin, B. M. (2008). Longitudinal relationships between occupational and domestic physical activity patterns and body weight in China. European Journal of Clinical Nutrition, 62, 13181325.

Ono, R., Hirata, S., Yamada, M. et al. (2007). Reliability and validity of the Baecke Physical Activity Questionnaire in adult women with hip disorders. BMC Musculoskeletal Disorders, 8:61doi:10.1186/1471-2474-8-61.
Parkes, K. R. (2006). Physical activity and self-rated health: Interactive effects of activity in work and leisure domains. British Journal of Health Psychology, 11 (3), 533-550.

Philippaerts, R. M., Westerterp, K. R., Lefevre, J. (1999). Doubly Labeled Water Validation of three Physical Activity Questionnaires. International Journal of Sports and Medicine, 20 (5), 284-289.

Puišienè, E., Kardelienè, L., Kardelis, K. (2008). Kauno miesto vyresniujų klasių vaikinų ir merginu gyvensenos skiriamieji bruožai. Ugdymas. Küno kultūra. Sportas, 1 (68), 73-79.

Richardson, M. T., Ainsworth, B. E., Wu, H., Jacobs, D. R., Leon, A. S. (1995). Ability of the Atherosclerosis Risk in Communities (ARIC)/Baecke Questionnaire to Assess Leisure-Time Physical Activity. International Journal of Epidemiology, 24 (4), 685-693.

Rombaldi, A. J., Menezes, A. M., Azevedo, M. R., Hallal, P. C. (2010). Leisure-time physical activity: Association with activity levels in other domains. Journal of Physical Activity \& Health, 7 (4), 460-464.

Rouse, P. C., Biddle, S. J. H. (2010). An ecological momentary assessment of the physical activity and sedentary behaviour patterns of university students. Health Education Journal, 69 (1) 116-124.

Seo, D. S., Torabi, M. R., Jiang, N., Fernandez-Rojas, X., Park, B. H. (2009). Correlates of College Students' Physical Activity: Cross-cultural differences. Asia-Pacific Journal of Public Health, 4 (21), 421-432.

Shuval, K., Weissblueth, E., Brezis, M., Araida, A., Dipietro, L. (2009). Individual and socio-ecological correlates of physical activity among Arab and Jewish college students in Israel. Journal of Physical Activity and Health, 6 (3), 306-314.

Wang, Y.,Tuomilehto, J. Jousilahti, P. et al. (2010). Occupational, commuting, and leisure-time physical activity in relation to heart failure among Finnish men and women. Journal of the American College of Cardiology, 28, 56 (14), 1140-1148.

WHO. (2011). Physical activity. Health topics. [2011 01 15]. Internet link: http://www.who.int/topics/physical activity/ en/

WHO. (2002). Physical inactivity - a leading cause of disease and disability, warns WHO [press release]. Geneva, Switzerland: WHO/23; April 4. 


\title{
LIETUVOS AUKŠTŲJU MOKYKLŲ STUDENTŲ FIZINIO AKTYVUMO SPORTUOJANT, DIRBANT IR LAISVALAIKIU SĄSAJOS
}

\author{
Brigita Miežienė, Laimutis Šiupšinskas, Rasa Jankauskienė \\ Lietuvos kūno kultūros akademija, Kaunas, Lietuva
}

\section{SANTRAUKA}

Tyrimo pagrindimas ir hipotezè. Su sportu nesusijęs fizinis aktyvumas dirbant, laisvalaikiu ir buityje dažnai yra nepakankamai i̇vertinamas kaip sveikatą veikiantis veiksnys. Kita vertus, ankstesni tyrimai atskleidé, kad energija, išeikvota dirbant ir laisvalaikiu, siejasi su energijos išeikvojimu sportuojant ir mankštinantis. Visgi studentai yra ypač mažai šiuo atžvilgiu analizuota grupè. Tikèjomès, kad mažesnis fizinis aktyvumas dirbant ir laisvalaikiu siesis su didesniu aktyvumu sportuojant.

Tikslas: nustatyti aukštujų mokyklų studentų fizinio aktyvumo sportuojant, dirbant ir laisvalaikiu sąsajas.

Metodai. Galutinę tyrimo imti sudare 867 Lietuvos aukštujų mokyklų studentai, 195 (22,5\%) iš jų buvo vyrai. Amžiaus ribos - 18-22 metai. Baecke kasdienio fizinio aktyvumo klausimynas (Baecke Questionnaire of Habitual Activity - Baecke et al., 1982) buvo naudojamas ivertinant fizini aktyvumą studentams sportuojant, dirbant ir laisvalaikiu.

Rezultatai. Vaikinu fizinis aktyvumas dirbant ir sportuojant buvo didesnis nei merginu ( $\mathrm{p}<0,0001)$, bet aktyvumas laisvalaikiu vaikinų ir merginų grupėse nesiskyrè $(\mathrm{p}=0,61)$. Vaikinai, kaip ir merginos, kurių aktyvumas dirbant buvo didesnis, du kartus dažniau buvo aktyvūs sportuodami nei tie studentai, kurių aktyvumas dirbant buvo mažesnis ( ̌̌ansų santykis ( ̌̌S $)=2,22$ [95\% PI 1,25-3,93] ir ŠS = 2,14 [95\% PI, 1,50-3,04] atitinkamai). Merginų, kurių aktyvumas laisvalaikiu buvo didesnis, beveik du kartus dažniau buvo aktyvios ir sportuodamos nei tos merginos, kurių aktyvumas laisvalaikiu buvo mažesnis ( $\breve{S} S=1,65$ [95\% PI 1,22-2,21]).

Aptarimas ir išvados. Fizinio aktyvumo sportuojant, dirbant ir laisvalaikiu sąsajų analizè nepatvirtino mūsų prielaidų. Šio tyrimo rezultatai leidžia teigti, kad mažesnis fizinis aktyvumas dirbant ir laisvalaikiu nelemia didesnio fizinio aktyvumo sportuojant tikimybès. Taigi fizinis aktyvumas sportuojant ir aktyvumas kitose gyvenimo srityse dera tarpusavyje ir, tikètina, priklauso nuo neitrauktų i ši tyrimą veiksnių, kurie gali veikti visas šias sritis kartu. Tolesnių tyrimų metu norint ištirti didesnį studentų kasdienį fizinį aktyvumą lemiančius veiksnius, reikètų apimti platesnị šių veiksnių spektrą.

Raktažodžiai: kasdienis fizinis aktyvumas, fizinio aktyvumo sritys, universiteto studentų veikla.

Gauta 2011 m. balandžio 20 d.

Received on April 20, 2011

Corresponding author: Brigita Miežienè Lithuanian Academy of Physical Education Sporto str. 6, LT-44221 Kaunas Lithuania

Tel +37037302638

E-mail bmieziene@gmail.com 